\title{
PENGARUH TERAPI KOMPLEMENTER MASSAGE PUNGGUNG TERHADAP TEKANAN DARAH PADA LANSIA DENGAN HIPERTENSI
}

\author{
IGA Ari Rasdini, Ni Made Wedri, VM Endang SP Rahayu, DewaGde putrayasa \\ JurusanKeperawatan, Poltekkes Kemenkes Denpasar, Jln. P. Moyo No. 33 A Denpasar \\ Email: rasdiniari@gmail.com
}

\begin{abstract}
ABSTRAK
Sekitar 90\% usia dewasa dengan tekanan darah normal akan berkembang menjadi hipertensi pada usia lanjut. Hipertensi pada usia lanjut mempunyai beberapa kekhususan, umumnya disertai dengan faktor resiko yang lebih berat. Masage punggung bermanfaat melancarkan peredaran darah dan memberikan efek tenang sehingga tekanan darah menjadi stabil. Penelitian ini bertujuan untuk mengetahui pengaruh terapi masase punggung terhadap tekanan darah pada lansia dengan hipertensi. Rancangan penelitian menggunakan quasy experiment dengan desain pretest-posttest control group design, jumlah sampel 20 orang tiap kelompok, dengan tehnik random sampling. Hasil penelitian menunjukkan rata rata kelompok perlakuan berusia 73 tahun dan kontrol berusia 75 tahun, jenis kelamin tiap kelompok 10 orang laki laki dan 10 orang perempuan. Pada kelompok perlakuan nilai systole pre-post $(164-148.5 \mathrm{mmHg})$, diastole pre-post $(85-80 \mathrm{mmHg})$. Kelompok control rata rata nilai systole pre-post $(167,7-151.2 \mathrm{mmHg})$, diastole $(87.5-77.5 \mathrm{mmHg})$.Uji Wilcoxon test didapatkan ada perbedaan yang signifikan tekanan darah pada kelompok perlakuan dengan $\mathrm{p}$ value systole adalah0.000, $\mathrm{p}$ value diastole 0.025 . Tidak ada perbedaan yang signifikan tekanan darah pada kelompok kontrol baik systole dengan pvalue 0.086 dan $p$ value diastole 0.140 . Ada pengaruh yang signifikan terapi komplementer massage punggung terhadap tekanan darah systole dengan $p$ value 0.000 dan $p$ value diastole adalah 0,028 . Direkomendasikan terapi massage punggung sebagai terapi non farmakologi untuk menstabilkan tekanan darah guna mencegah komplikasi kardiovaskuler
\end{abstract}

Kata Kunci : massage punggung; tekanan darah; hipertensi; lansia.

\section{THE INFLUENCEOF COMPLEMENTERTHERAPYONBLOODPRESSUREINELDERLYWITH HYPERTENSION AT GIANYAR SUKAWATI II HEALTH CENTRE}

\begin{abstract}
Approximately 90\% of adults with normal blood pressure will develop hypertension in old age. Hypertension in the elderly has several characteristics, generally accompanied by more severe risk factors. Back massage is useful for blood circulation and provides a calming effect so that blood pressure becomes stable. This study was aimed to determine the effect of back massage therapy on blood pressure in the elderly with hypertension. The research design used a quasi-experimental design with a pretest-posttest control group design, the number of samples were 20 people per group, with random sampling technique. The results showed that the average age of the treatment group was 73 years old and the control group was 75 years old, the sexes of each group were 10 men and 10 women. In the treatment group the value of pre-post systole (164$148.5 \mathrm{mmHg}$ ), pre-post diastole (85-80 $\mathrm{mmHg})$. The control group averaged pre-post systole values (167.7 - $151.2 \mathrm{mmHg}$ ), diastole $(87.5-77.5 \mathrm{mmHg})$. The Wilcoxon test showed that there was a significant difference in blood pressure in the treatment group with $p$-value of systole being $0.000, p$-value of diastolic 0.025 . There is no significant difference in blood pressure in the control group, both systole with $p$ value 0.086 and $p$ value diastole 0.140 . There is a significant effect of complementary back massage therapy on systolic blood pressure with a $p$ value of 0.000 and a diastolic $p$ value of 0.028 . Back massage therapy is recommended as a non-pharmacological therapy to stabilize blood pressure to prevent cardiovascular complications
\end{abstract}

Key Ward ; back massage; blood pressure; hypertension; elderly

Jurnal SMART Keperawatan is licensed under a Creative Commons Attribution-ShareAlike 4.0 International License. 


\section{LATAR BELAKANG}

Seiring dengan meningkatnya usia maka penyakit kronis juga semakin meningkat, sehingga usia lanjut lebih banyak membutuhkan terapi dengan obat untuk penatalaksanaan berbagai penyakit yang diderita (Bestari dan Dwi, 2016) Hipertensi merupakan suatu penyakit yang prevalensinya meningkat dengan bertambahnya usia. Sekitar 90\% usia dewasa dengan tekanan darah normal akan berkembang menjadi hipertensi pada usia lanjut (Amanda dan Martini, 2018). Hipertensi pada usia lanjut mempunyai beberapa kekhususan, umumnya disertai dengan faktor resiko yang lebih berat, sering disertai penyakit - penyakit lain yang mempengaruhi penanganan hipertensi seperti dosis obat, pemilihan obat, efek samping atau komplikasi karena pengobatan lebih sering terjadi, terdapat komplikasi organ target, kepatuhan berobat yang kurang, sering tidak mencapai target pengobatan dan lain - lain (Wahyuningsih dan Astuti, 2012). Kesemua ini menjadikan hipertensi usia lanjut tergolong dalam risiko kardiovaskular yang tinggi atau sangat tinggi. Oleh karena itu penanganan hipertensi pada usia lanjut membutuhkan perhatian yang jauh lebih besar ( Supraptia dkk, 2014)

Penelitian Nurhidayati dkk (2018) menemukan bahwa pada lansia umur 60-64 tahun terjadi peningkatan hipertensi sebesar 2,18 kali, umur 65-69 tahun 2,45 kali, > 70 tahun 2,97 kali. Hal ini terjadi karena pada usia tersebut arteri besar kehilangan kelenturannya dan menjadi kaku karena itu darah pada setiap denyut jantung dipaksa untuk melalui pembuluh darah yang sempit dari pada biasanya dan menyebabkan naiknya tekanan darah.. Umur merupakan salah satu faktor yang mempengaruhi tekanan darah tinggi (hipertensi). Semakin tua seseorang maka semakin besar resiko terserang hipertensi (Adam, 2019). Relaksasi merupakan tindakan yang harus dilakukan pada setiap terapi antihipertensi (Sulistyarini, 2013). Apabila tekanan darah terlalu tinggi, pembuluh darah yang relaks akan terjadi vasodilatasi pembuluh darah sehingga akan menyebabkan tekanan darah turun dan kembali normal. Untuk membuat tubuh menjadi rileks dapat dilakukan dengan beberapa cara seperti terapi musik klasik, yoga, tehnik nafas dalam, dan terapi masase (Yanti dkk, 2019).

Banyak dokter tidak mengobati hipertensi pada usia lanjut sampai optimal (mencapai target kurang dari 150/90 $\mathrm{mmHg}$ ) mengingat kekuatiran terjadinya efek samping pengobatan yang lebih besar dibandingkan manfaatnya (Kuswardhani, 2006) Selain itu ada juga beberapa faktor lain yang perlu diperhatikan, yaitu faktor yang turut mempengaruhi respon pasien usia lanjut terhadap terapi anti hipertensi, seperti aterosklerosis, perubahan kardiovaskular akibat proses degeneratif, penurunan respons baroreflex dan lain- lain (Sartik dkk, 2017). Penelitian ini bertujuan untuk mengetahui pengaruh terapi massage punggung terhadap tekanan darah pada lansia dengan hipertensi di Puskesmas Sukawati II Gianyar.

\section{METODE}

Desain penelitian eksperimen memiliki bermacam-macam jenis desain. Metode eksperimen dalam penelitian ini menggunakan jenis desain penelitian dengan metode pretestposttest control group design (Sugioyono, 2019) Penelitian dilakukan di Wilayah Puskesmas Sukawati II Kabupaten Gianyar . Waktu penelitian dilakukan selama 5 bulan yaitu mulai bulan April s.d Oktober 2019. Populasi dalam penelitian ini adalah lansia dengan hipertensi, mengkonsumsi obat anti hipertensi, usia $>60$ thn Dalam penelitian ini jumlah sampel pada masing masing kelompok berjumlah 20 orang, dengan tehnik random sampling. Kriteria sampel adalah Lansia berumur $\geq 60$ tahun, hipertensi ( TS : $>140$ $\mathrm{mm} \mathrm{Hg}$ ), tidak terkontrol, mengkonsumsi obat anti hipertensi $>2$ tahun. Analisa data diolah dengan teknik analisa data yaitu mempergunakan uji parametrik. Syarat untuk melakukan uji parametrik yaitu selain data dalam bentuk skala interval, data juga harus berdistribusi normal. Maka, dilakukan uji normalitas data dengan menggunakan uji kolmogorov smirnov (Sujarweni, 2019). Dikatakan berdistribusi normal apabila dikatakan nilai $\alpha<$ Asymp.sig (1-tailed). Untuk 
mengetahui tekanan darah sebelum dan sesudah diberikan terapi massage punggung dilakukan uji t sampel berpasangan (paired ttes) dengan alpha 0,05 (Sujarweni, 2019).

\section{HASIL}

Karakteristik berdasarkan umur dan jenis kelamin pada kelompok perlakuan dan kelompok kontrol.

Tabel1. Distribusi karakteristik Lansia dengan Hipertensi di UPT Kesmas Sukawati II Gianyar

\begin{tabular}{lcc}
\hline \multirow{2}{*}{ Karakteristik } & \multicolumn{2}{c}{ Kelompok } \\
\cline { 2 - 3 } & Perlakuan & Kontrol \\
\hline Umur & $73,3 \pm 8,50$ & $75,3 \pm 6,40$ \\
\hline Jenis Kelamin & & \\
\hline$-\quad$ Laki-laki & 10 & 10 \\
$-\quad$ Perempuan & 10 & 10 \\
\hline Total & 20 & 20 \\
\hline
\end{tabular}

Berdasarkan Tabel 1 di atas menunjukkan bahwa umur responden pada kelompok perlakuan rata-rata 73,3 $\pm 8,50$ tahun dan pada kelompok kontrol 75,3 $\pm 6,40$ tahun dengan nilai $p$ value sebesar 0,418 . Ditinjau dari jenis kelamin diperoleh pada kedua kelompok, jumlah laki-laki dan jumlah perempuan masing-masing sebanyak 10 orang dengan nilai $p$ value sebesar 1,00 .

Tekanan Darah pada Lansia dengan Hipertensi pada Kelompok Perlakuan

Tabel 2. Deskriptif tekanan darah pre dan post pada Kelompok Perlakuan

\begin{tabular}{ccccc}
\hline \multirow{2}{*}{$\begin{array}{c}\text { TekananDa } \\
\text { rah }\end{array}$} & \multicolumn{2}{c}{ Sistole } & \multicolumn{2}{c}{ Diastole } \\
\cline { 2 - 5 } & Pre & Post & Pre & Post \\
\hline Mean & 164,0 & 148,5 & 85,0 & 80,0 \\
Median & 160,0 & 150,0 & 90,0 & 80,0 \\
Min & 150,0 & 140,0 & 70,0 & 70,0 \\
Maks & 180,0 & 140,0 & 70,0 & 70,0 \\
SD & 7,5 & 6,7 & 9,4 & 6,4 \\
\hline
\end{tabular}

Tabel diatas menunjukan rata rata terjadi penurunan nilai systole post-pre 164$148,5 \mathrm{mmHg}$ dan nilai diastole post-pre tetap (80-85 mmHg) pada kelompok perlakuan
Tekanan Darah pada Lansia dengan Hipertensi pada Kelompok Kontrol

Tabel 3. Diskriptif tekanan darah pre dan post pada kelompok kontrol

\begin{tabular}{ccccc}
\hline Tekanan & \multicolumn{2}{c}{ Sistole } & \multicolumn{2}{c}{ Diastole } \\
\cline { 2 - 5 } Darah & Pre & Post & Pre & Post \\
\hline Mean & 167,7 & 151,2 & 87,5 & 77,5 \\
Median & 170,0 & 150,0 & 90,0 & 80,0 \\
Min & 160,0 & 140,0 & 70,0 & 70,0 \\
Maks & 180,0 & 160,0 & 90,0 & 90,0 \\
SD & 6,1 & 6,4 & 5,5 & 7,1 \\
& & & & \\
\hline
\end{tabular}

Berdasarkan hasil analisis data pada tabel 3 tekanan darah sistole-pre tertinggi sebesar $180 \mathrm{mmHg}$ dan terendah sebesar 160 $\mathrm{mmHg}$, sistole-post tertinggi diketahui sebesar $160 \mathrm{mmHg}$ dan terendah sebesar $140 \mathrm{mmHg}$, nilai rata-rata tekanan darah sistole-pre sebesar $167,7 \pm 6,1 \mathrm{mmHg}$. Nilai rata-rata tekanan darah sistole-post sebesar 151,2 $\pm 6,4$ $\mathrm{mmHg}$. Diastole tertinggi pre rata rata 87.5 dan terendah $77.5 \mathrm{mmHg}$.

\section{Perbedaan Tekanan Darah Lansia pada kelompok perlakuan dan kelompok kontrol}

Tabel 4. Perbedaan Tekanan Darah Lansia pada kelompok Perlakuan dan kelompok kontrol diUPT Sukawati II Gianyar

\begin{tabular}{lcll}
\hline Kelompok & $\begin{array}{c}\text { Tekanan } \\
\text { Darah }\end{array}$ & $\begin{array}{l}\mathbf{P} \\
\text { value }\end{array}$ & Keterangan \\
\hline Perlakuan & Sistole & 0,000 & signifikan \\
& Diastole & 0,025 & signifikan \\
\hline Kontrol & Sistole & 0,086 & Tidak Signifikan \\
& Diastole & 0,140 & Tidak Signifikan \\
\hline
\end{tabular}

Tabel diatas menunjukkan tidak ada perbedaan yang signifikan tekanan darah sistole pada kelompok kontrol dengan $p$ value 0.086 . Tidak ada perbedaan yang signifikan tekanan darah diastole pada kelompok kontrol dengan $p$ value 0.000 . Ada perbedaan yang signifikan tekanan darah sistole pada kelompok perlakuan dengan $p$ value 0.000 . Ada perbedaan yang signifikan tekanan darah diastole pada kelompok perlakuan dengan $p$ value 0.025 . 
Perbedaan efek yang ditimbulkan setelah dilakukan terapi komplementer massage punggung dilakukan dengan uji Mann Whitney.

Tabel 5.Pengaruh Terapi Komplementer Massage Punggung terhadap Tekanan Darah pada lansia dengan hipertensi (kelompokperlakuan) di UPT Kesmas II Sukawati Gianyar

\begin{tabular}{ll}
\hline Tekanan Darah & P value \\
\hline Sistole & 0,000 \\
\hline Diastole & 0,028 \\
\hline
\end{tabular}

Ada pengaruh yang signifikan terapi komplementer massage punggung terhadap tekanan systole dengan $p$ value 0.00 , dan nilai diastole dengan $p$ value 0.028 .

\section{PEMBAHASAN}

Menurut WHO lanjut usia (lansia) adalah kelompok penduduk yang berumur 60 tahun atau lebih (Kiik dkk, 2018). Umur responden pada kelompok perlakuan rata-rata $73,3 \pm 8,50$ tahun dan pada kelompok kontrol 75,3 $\pm 6,40$ tahun dengan nilai $p$ value sebesar 0,418 . Ditinjau dari jenis kelamin diperoleh pada kedua kelompok, jumlah laki-laki dan jumlah perempuan masing-masing sebanyak 10 orang dengan nilai $p$ value sebesar 1,00. Hal ini berarti karakteristik responden yang ditinjau berdasarkan umur dan jenis kelamin adalah tidak berbeda signifikan, dengan kata lain kedua kelompok layak untuk diperbandingkan.

Berdasarkan hasil analisis data pada kelompok kontrol tekanan darah sistole-pre tertinggi sebesar $180 \mathrm{mmHg}$ dan terendah sebesar $160 \mathrm{mmHg}$, sistole-post tertinggi diketahui sebesar $160 \mathrm{mmHg}$ dan terendah sebesar $140 \mathrm{mmHg}$, nilai rata-rata tekanan


sistole-post sebesar 151,2 $\pm 6,4 \mathrm{mmHg}$. Diastole tertinggi pre rata rata $90 \mathrm{mmHg}$ dan terendah $70 \mathrm{mmHg}$. Dari hasil tersebut terjadi penurunan tekanan darah baik sistol maupun diastole sesudah diberikan intervensi terapi komplementer massage punggung. Relaksasi merupakan tindakan yang harus dilakukan pada setiap terapi antihipertensi (Tyani dkk, 2015). Apabila tekanan darah terlalu tinggi, pembuluh darah yang relaks akan terjadi vasodilatasi pembuluh darah sehingga akan menyebabkan tekanan darah turun dan kembali normal. Untuk memperoleh penurunan tekanan darah tersebut, setiap responden dilakukan terapi massage punggung $2 x$ seminggu selama 3 minggu, 15 mnt setiap kali terapi.

Hasil penelitian ditemukan tidak ada perbedaan yang signifikan tekanan darah systole pada kelompok kontrol dengan pvalue : 0.086 dan diastole pada kelompok kontrol dengan $p$ value : 0.140. Relaksasi merupakan tindakan yang harus dilakukan pada setiap terapi antihipertensi. Apabila tekanan darah terlalu tinggi, pembuluh darah yang relaks akan terjadi vasodilatasi pembuluh darah sehingga akan menyebabkan tekanan darah turun dan kembali normal (Udani, 2016). Untuk membuat tubuh menjadi rileks dapat dilakukan dengan beberapa cara seperti terapi music klasik, yoga, tehnik nafas dalam, dan terapi masase ( Anggariawan dan Kushartanti, 2014). Pada hipertensi tidak terkontrol, walaupun obat secara rutin dikonsumsi, tekanan darah tetap tinggi (Darussalam dan Warseno, 2017). Hal ini dibuktikan dengan pemberian terapi massage punggung pada kelompok perlakuan, didapatkan ada perbedaan yang signifikan tekanan darah systole pada kelompok perlakuan dengan $p$ value 0.000 . Ada perbedaan yang signifikan tekanan darah diastole pada kelompok perlakuan dengan $p$ value 0.025 .

Perbedaan efek yang ditimbulkan setelah dilakukan terapi komplementer massage punggung diperoleh hasil adanya pengaruh yang signifikan terapi komplementer massage punggung terhadap tekanan systole dengan $p$ value 0.00 , dan nilai $p$ value diastole adalah 0.028 . Massage mempunyai pengaruh tertentu terhadap jaringan tubuh. Selain itu tekanan, arah gerakan, pengulangan, dan iramanya menentukan pengaruhnya (Harahap dan Sagala, 2017). Keberhasilan massage jg ditentukan oleh ilmu dan pengalaman massage. Dengan teknik menekan dan mendorong secara bergantian menyebabkan terjadinya pengosongan dan pengisian pembuluh vena dan lymphe, sehingga 
membantu ekskresi \& pemberian nutrisi dan 02 ke dlm jaringan ( Juliantara dkk, 2015).

Massage mempercepat pengosongan dan pengisian cairan sehingga memperlancar sirkulasi dan pembebasan sisa-sisa metabolisme, memperlancar penyajian nutrisi sehingga mempercepat proses pemulihan. Terhadap otot yg mengalami cedera, massage membantu penyebaran traumatic-effusion dan suplai darah terhadap jaringan (Sa'roni dan Graha, 2019). Back massage atau massage punggung adalah tindakan masage punggung dengan usapan perlahan dengan kecepatan 60 kali usapan permenit. Kedua tangan menutup suatu area yang lebarnya $5 \mathrm{~cm}$ pada kedua sisi tonjolan tulang belakang dari ujung kepala sampai ke area sacrum. Gosokan punggung yang efektif memerlukan waktu 3 sampai 5 menit (Istyawati dkk, 2020). Masase punggung atau back massage merupakan stimulasi kulit tubuh dengan pemijatan dan memberikan sentuhan pada punggung dan bahu yang dapat melemaskan otot di luar sumber nyeri dan dilakukan sekitar 10 menit untuk mencapai hasil relaksasi yang maksimal ( Puspitasari dan Astuti, 2017).

Pemberian masase pada punggung akan merangsang saraf beta A yang berdiameter besar yang memiliki kecepatan 30$70 \mathrm{~m} /$ detik. Saraf beta A juga akan menyalurkan impuls melewati traktus spinotalamus atau jalur asendens kemudian akan berakhir pada bagian otak tengah. Kemudian impuls ini akan menstimulasi daerah tersebut untuk mengirimkan kembali ke bawah yaitu pada kornu dorsalis medula spinalis atau sistem kontrol desenden yang bekerja dengan melepaskan neuromodulator yang menghambat transmisi nyeri yaitu enkefalin ( Supliyani, 2017). Enkefalin ini yang akan menghambat pengeluaran subtansi $P$ pada kornu dorsalis sehingga transmisi impuls nyeri dapat dihambat (Purnama, 2018).

\section{KESIMPULAN DAN SARAN}

Karakteristik responden : Usia pada kelompok perlakuan rata-rata 73,3 tahun dan pada kelompok kontrol 75,3 tahun, lakilaki 10 orang, perempuan 10 orang baik pada kelompok kontrol maupun kelompok perlakuan.

Hasil pengukuran tekanan darah systole/diastole pada kelompok perlakuan dengan mean 164/85 mmHg (pretest) danmean $148,5 / 80 \mathrm{mmHg}$ (posttest), dengan $p$ value 0,000 pada systole dan $p$ value 0,025 pada diastole. Sedangkan tekanan darah systole/diastole pada kelompok kontrol dengan mean $167,7 / 87,5 \mathrm{mmHg}$ (pretest) dan mean $151,2 / 77,5 \mathrm{mmHg}$ (posttest), dengan $p$ value 0,086 pada systole dan $p$ value 0,140 pada diastole.

Ada pengaruh yang signifikan terapi komplementer massage punggung terhadap tekanan systole dengan pvalue 0.000 , dannilai diastole dengan $p$ value 0.028 .

\section{SARAN}

Masage punggung sebagai rekomendasi terapi non farmakologi untuk menstabilkan tekanan darah guna mencegah komplikasi kardiovaskular pada lansia dengan hipertensi. Perlu adanya pelatihan kader tentang massage punggung sebagai terapi komplementar untuk mengatasi berbagai keluhan penyakit degenerative pada lansia

\section{REFERENSI}

Adam, Lusiane. (2019). Determinan Hipertensi Pada Lanjut Usia. Jambura Health and Sport Journal, 1(2), 82-89. https://doi.org/10.37311/jhsj.v1i2.2558

Amanda, Desi dan Martini Santi. (2018). The Relationship between Demographical Characteristic and Central Obesity with Hypertension. Jurnal Berkala Epidemiologi, 6(1), hal 43 - 50. https://doi.org/10.20473/jbe.v6i12018.

Anggariawan, Nova dan Wara, Kushartanti. (2014). Pengaruh Terapi Masase, Terapi Latihan, Dan Terapi Kombinasi Masase Dan Latihan Dalam Penyembuhan Cedera Bahu Kronis Pada Olahragawan. Medikora. 12(1)

Bestari, Beningtyas K., dan Wati D. N. K.( 2016). Penyakit Kronis Lebih Dari Satu Menimbulkan Peningkatan Perasaan Cemas Pada Lansia di Kecamatan 
Cibinong. Jurnal Keperawatan Indonesia,19(1), 49-55.

Darussalam, Miftafu dan Warseno, Agus. (2017). Faktor yang Berhubungan dengan Pasien Hipertensi Tidak Terkontrol di Puskesmas. Jurnal Keperawatan Klinis Dan Komunitas, 1(2), 72-80.

Harahap, Novita. S., dan Nila Sari S. S.(2017). Pengaruh Pemberian Manipulasi Sport Massage. Journal kesehatan dan Olahraga. 1(2), 11-21.

Istyawati, Purwani, dkk. (2020). Efektifitas Slow Stroke Back Massage (Ssbm) Dalam Menurunkan Skala Nyeri Kepala Pasien Hipertensi Di Rumah Sakit Mitra Siaga Tegal. Coping: Community of Publishing in Nursing, 8(2), 207. https://doi.org/10.24843/coping.2020.v08.i 02.p14

Juliantri, Veny, dkk. 2015. Efektivitas Massage Ekstremitas terhadap Perubahan Tekanan Darah pada Pasien Hipertensi di Klinik Pratama Universitas Tanjungpura Tahun 2015. Journal Cerebellum 1(3), 247-265.

Kiik, Stefanus. M. dkk. 2018. Peningkatan Kualitas Hidup Lanjut Usia (Lansia) Di Kota Depok Dengan Latihan Keseimbangan. Jurnal Keperawatan Indonesia, 21(2), 109-116. https://doi.org/10.7454/jki.v21i2.584

Kuswardhani, R. (2006). Penatalaksanaan Hipertensi Pada Lanjut Usia. Journal of Internal Medicine, 7(2), 135-140.

Nurhidayati, Istiana, dkk. (2018). Penderita Hipertensi Dewasa Lebih Patuh daripada Lansia dalam Minum Obat Penurun Tekanan Darah. Jurnal Kesehatan Masyarakat Indonesia, 13(2), 4-8.

Supliyani, Elin. (2017). Pengaruh Masase Punggung Terhadap Intensitas nyeri persalinan Kala 1 di kota Bogor. Midwife journal. 3(1), 22-29.

Purnama, Y. H. C. (2018). Pengaruh Bekam Terhadap Penurunan Nyeri Pada Klien Dengan Trapezius Myalgia Pada Pekerja Angkut Di Kecamatan Jelbuk Jember. The Indonesian Journal of Health Science. September, 66. https://doi.org/10.32528/ijhs.v0i0.1524
Puspitasari, Indah dan Astuti, Dwi. (2017). Tehnik Massage Punggung Untuk Mengurangi Nyeri Persalinan Kala I. Jurnal IImu Keperawatan Dan Kebidanan, $8(2)$, 100. https://doi.org/10.26751/jikk.v8i2.289

Tyani, Endar S., dkk .(2015). Efektifitas relaksasi otot progresif terhadap tekanan darah pada penderita hipertensi esential. Journal Online Mahasiswa.2(2). 1068 1075.

Sartik. (2017). Risk Factors and the Incidence of Hipertension in Palembang. Jurnal IImu Kesehatan Masyarakat, 8(3), 180-191. https://doi.org/10.26553/jikm.2017.8.3.180 $-191$

Sa'roni, Subhan dan Ali Graha, S. (2019). Efektifitas Massage Terapi Cedera Olahraga Terhadap Nyeri Tumit Dan Nyeri Otot Tibialis Pada Atlet Futsal Sma Negeri 1. Medikora XVIII(2), 56-63.

Sugiyono. (2019). Metode Penelitian Kuantitatif dan Kualitatif. Bandung. Alfabeta.

Sujarweni, Wiratna. (2019). SPSS untuk Penelitian. Yogyakarta. Pustaka baru press

Sulistyarini, Indahria. (2013). Terapi Relaksasi untuk Menurunkan Tekanan Darah dan Meningkatkan Kualitas Hidup Penderita Hipertensi. Jurnal Psikologi, 40(1), 28-38. https://doi.org/10.22146/jpsi.7064

Suprapti Budi, dkk. 2014. Permasalahan Terkait Obat Antihipertensi pada Pasien Usia Lanjut di Poli Geriatri RSUD Dr.Soetomo, Surabaya. 1(2), 36-41.

Udani, Giri. 2016. Pengaruh Massase pada Penderita Hipertensi di UPTD Panti Tresna Werdha Lampung Selatan. Jurnal Kesehatan, $\quad 7(3), \quad 503$. https://doi.org/10.26630/jk.v7i3.236

Wahyuningsih, \& Astuti, Endri. 2016. Faktor Yang Mempengaruhi Hipertensi pada Usia Lanjut. Jurnal Ners Dan Kebidanan Indonesia, $\quad 1(3), \quad 71$. https://doi.org/10.21927/jnki.2013.1(3).7175

Yanti, Etri. (2019). Efektifitas Massase 
Punggung Dan Kaki Terhadap Tekanan Darah Pada Penderita Hipertensi. Jurnal Kesehatan Medika Saintika, 10(1), 18. https://doi.org/10.30633/jkms.v10i1.305 